\section{Science Overlooked}

THE British government has been commendably resolute in its efforts, in the past few months, to make Britain a part of Europe again, but its arrangements for celebrating the occasion have been curiously haphazard. Altogether, something like $£ 300,000$ has been spent on what is somewhat euphemistically called a "Fanfare for Europe"--a programme of concerts, theatrical performances and exhibitions devised by a committee with Lord Goodman as chairman. It may be that Lord Goodman is the best of all Pooh-Bahs, but he seems to have fumbled badly. Although the objective seems to have been to draw attention to the cultural relationship between Britain and the mainland which has existed for the past several centuries and which has now, with luck, become stronger, the programme which has been devised (Fanfare for Europe, Arrow Books, £0.70) is almost entirely innocent of attempts to demonstrate that many of the most important links between Britain and the rest of Europe have their roots in science. The nearest that the official programme comes to a recognition of the importance of science is an exhibition of ancient boats, recently dug up, at the National Maritime Museum. For the rest, there is not merely plenty of good music but a competition in karate between Britain and France, a basketball tournament, a volleyball match between teenage teams from Scotland and Belgium, an exhibition of stamps and other sporting contests, in fencing and weight-lifting, all too familiar as a means of disrupting international relations, not of cementing them. It is true that Lord Goodman's committee may not be the one solely responsible for the entire neglect of science in this programme of events-Lord Mancroft, a famous after dinner speaker, had a parallel committee responsible for what are called "other events", the fencing and the weight-lifting. The most charitable explanation is that science fell between the two committees; the most likely is that it was forgotten.

What might the committees have done? Especially with the Copernicus quincentenary, even the good Lords Goodman and Mancroft might have been moved to mark the reunification of Britain with Europe by recalling the time when the foundations of modern science were constructed by Tycho, Keppler, Copernicus, Galileo and ultimately Newton. They might also have remembered the several periods in European history when the scientific community has been more strongly welded together than any other community, with the possible exception of the Catholic Church. Did Davy and Faraday go gallivanting about France during the Napoleonic Wars for nothing? And is there not at least something favourable to be said for the way in which there has grown up several strong scientific institutions in Europe, of which CERN is the most conspicuous example (and several bad ones as well), whose work deserves some recognition in what is supposed to be a celebration of cultural links.

The neglect of science in Fanfare for Europe is not merely a debating point. Given the Prime Minister's devotion to music, it may be held that music, even pop music, is what the occasion called for. And it is certainly true that literature is also dealt with skimpily in the Fanfare, as are the humanities. But the overriding issue is whether it is in any sense proper that when people, even Lords Goodman and Mancroft, think of culture, they should think first of those kinds of culture which can be most easily exhibited by means of a few telephone calls to impresarios, theatrical agents and museums. The truth is that the contribution of European scholarship in general and European science in particular to the fabric of modern life is as much cultural as practical and is on all counts indispensable. To forget this is often forgiven but is unforgivable.

In practical terms, what Fanfare for Europe might have included is an exhibition to show how the foundations for modern science were laid in Western Europe, how the Cartesians raised the banner of applied mathematics, how people such as Gauss and Huyghens were able to conjure up insight out of thin air and how the experimentalists such as Volta, Lavoisier, Black and Faraday (to mention only a few) created the sense which now runs through science that a theory is above all a concept to be tested. And if by any chance the organizing committee had run short of interesting topics with which to deal, there would always have been the half century which began with Darwin and Maxwell and which, by the first decade of this century, had reconstructed modern science and had drawn the whole of Europe into the enterprise. Even to imply by default that these great happenings are not cultural is to deny what everybody knows--that the way in which all people regard the world they live in has been transformed as much by scientific discovery as by any other intellectual process with its roots in the Renaissance. To be sure, it is often harder to make all this come alive than to remind people that Beethoven was a genius, but that is no excuse for not trying. The simple truth, however, is that between them Lords Goodman and Mancroft have done a shallow job. In many ways, the Prime Minister might have been better advised to have substituted for Fanfare for Europe a public holiday on January 1, widely kept as such in any case.

\section{Years Ago}

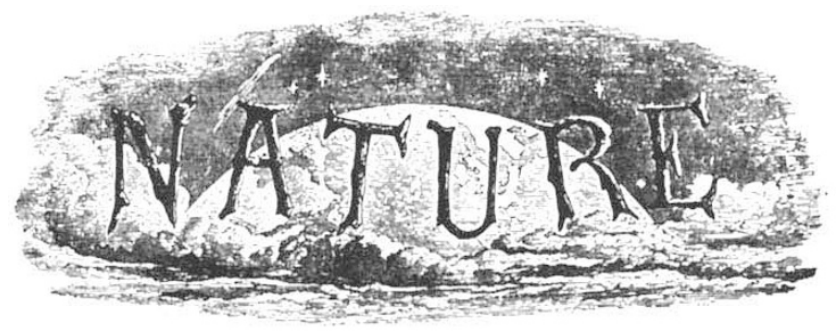

NOTES

W E believe that a reply has been received from the Government on the subject of the Arctic Expedition, which goes far to justify all that was said in our leader last week on the subject; for although the Government does not refuse absolutely to comply with the wishes of the deputation, all action will, unless strenuous efforts are made, be postponed for a year. We repeat that the deputation did not represent Science so broadly as it onght to have been represented; and we add, that if the Government thought so, it was, in our opinion, perfectly justified in refusing the demands made upon the national purse. To a certain extent, what happened in the case of the Eclipse Expedition of 1870 hins been now repeated. Our readers will recollect that on that occasion the mere persond application of the Astronomer Royal wa; at once very properly refused, while a proper representation by the leading Societies was at once as promptly acceded to.

From Nature, 7, 188 and 189, January 9, 1873. 